\title{
Food Prices and Modern Retail: The Case of Delhi
}

\author{
Bart Minten \\ International Food Policy Research Institute, New Delhi Office, b.minten@cgiar.org \\ Thomas Reardon \\ Michigan State University, reardon@msu.edu \\ Rajib Sutradhar \\ Jawaharlal Nehru University, rajibsutradhar@gmail.com
}

\section{August 2009}

Summary. - Modern retail is quickly becoming an important driver of changes in food markets in developing countries. However, the impact of this development on basic food prices facing urban consumers is not well understood. In a detailed case study of Delhi, modern retail is shown to emerge quickly, offering more labeled and branded food products and more choice than traditional markets. We further find that modern retail at its mere incipience in India sells basic foods mostly at the same or lower prices than traditional retail and might thus become an important contributor to improved urban food security.

Keywords. - Asia, India, modern retail, supermarkets, food prices, consumers, urban food markets, food quality, public distribution system

JEL - D40, L11, L81, O18, Q13 


\section{Food Prices and Modern Retail: The Case of Delhi}

\section{INTRODUCTION}

Modern retail is quickly becoming an important driver of changes in food markets in developing countries. For example, it is estimated that its share in retail food markets has increased from 5-10\% in 1990 to 50-60\% today in South America, South Africa, and developing East Asia outside China and that it increased from 5\% in 1990 to $20-50 \%$ today in Mexico, Central America and Southeast Asia (Reardon and Timmer, 2007). However, the impact of these market changes on the welfare of consumers is still not well understood (World Bank, 2008; Swinnen, 2007; Minot and Roy, 2007).

There is surprisingly little empirical evidence on the effect of the recent spread of modern retail on consumers and as competition for traditional retailers in developing countries. Three types of analysis are found in the literature.

A first strand of literature examines nutritional impacts of the spread of supermarkets. While there have not yet been survey-based analyses of the direct relation between shopping at supermarkets and nutritional and diet composition effects, there has been some indirect evidence. Asfaw (2007) finds for Guatemala that consumers that do some of their shopping at supermarkets also tend to consume more processed food (but not necessarily from supermarkets). Neven et al. (2006), in the early-stage modern retail situation of urban Kenya, show that consumers tend mainly to buy processed foods and staples from supermarkets, but mainly depend on traditional retailers for fresh produce. Hawkes (2008) examined recent survey 
evidence from Tunisia of shopping at supermarkets' correlation with consumers' food consumption variety and quantity and finds some correlation.

A second strand of the literature examines the profile of consumers shopping at supermarkets. The 'classic' hypothesis on this was in Goldman (1974) which argued that modern retail's structure would be amenable mainly or only to rich consumers in developing countries who could drive to stores, buy big units, store the products, and afford infrequent large shopping bills. But this early work did not use consumer or retail surveys, just anecdotal evidence. More recent work (part of a still very small body of studies) has been more survey-based, and has tended to show that in the early stages of supermarket penetration (such as the case in India now), it is mainly upper income and middle class consumers who shop at supermarkets (for Vietnam, see Figuié and Moustier, 2009; for Kenya, Neven et al., 2006; and for southern India, Chengappah, 2007).

A third strand of the literature examines pricing practices by modern retail in developing countries. In an overview of recent evidence, Minten and Reardon (2008) find that; (1) in the early stages of penetration of modern retail in developing countries, prices offered in modern retail are generally equal or higher (compared to traditional retail prices) for processed foods and significantly higher for fresh foods, especially produce; For example, Ho (2006) illustrates this for Hong Kong; ${ }^{1}$ (2) in the intermediate stages, processed food is cheaper in supermarkets but the results for fresh food are mixed (tending toward only a few mass produce items being cheaper but many others being more expensive in modern retail); (3) in the advanced stage, food prices in modern retail tend to be generally lower (than traditional retail) for almost all types of food products, in particular because procurement systems become more efficient through better 
supply chain management and in-store and in-distribution-center inventory management and handling. The latter was also illustrated by Ho (2006) for Hong Kong, in the 2000s.

However, the great majority of the price-comparison studies reviewed have the general weaknesses of: (1) being based on very small samples or even just anecdotal cases rather than being based on representative sample-surveys; and (2) failing to control for important quality and/or unit size differences of food between modern and traditional retail. The upshot is that there is an important gap in the literature due to the lack of survey-evidence based comparisons of prices and quality between the two retail segments.

The above issue - the effects of modern retail on food prices facing the urban poor - is an emerging theme of debate in India. There are two contested sides to this issue: one side relying on a conventional or traditional view (as noted above) of modern retail in the developing world, that its sales are focused on the rich and so the prices must be higher than in traditional markets, and the other side (such as expressed in Gulati and Reardon, 2008), positing that that modern retail has the ability, possibly because of greater efficiency in product procurement and merchandizing, to retail food at lower prices than traditional retailers, even at the early stage of supermarket penetration of Indian urban food markets. While the relevance of the effects of alternative marketing systems on food prices and thus on food security is of long-standing interest in developing countries, the timeliness of the debate on food pricing by modern versus traditional retailers was heightened in 2008 due to a crisis of food price inflation, and due to an on-going debate about whether to liberalize foreign direct investment that would spur yet faster the diffusion of modern retail in India (e.g. Joseph et al., 2008).

Despite the importance of the debate given its potential implication for food security, to date no survey-based evidence has been brought to bear to test the hypotheses put forward by 
these sides. We aim to address that gap in this paper, for the case of Delhi. India, and Delhi in particular, is an interesting case to study modern food retail given that modern retail diffusion is just starting and given the food price policy and modern retail debates noted above. We focus on three questions, each time differentiating between modern and traditional retailers for staples, fruit, and vegetables: (1) what is the pattern of retail sales of key selected food products and retail outlet diffusion in Delhi? (2) How do the prices of those products differ over types of retailers, controlling for product quality? (3) How does the quality of the food products differ over the types of retailers? ${ }^{2}$

To answer these questions, we conducted a survey in Delhi in the beginning of 2009 for eight major food items - representing key staple processed foods (rice, wheat flour, and mustard oil) and among the most common fruits and vegetables (bananas and apples, and onions, potatoes, and tomatoes) - in randomly selected areas in the city. A census of all food retail outlets was done and a survey was implemented of traditional as well as modern retail outlets to measure price and quality differentials between the different categories of outlets.

The specific contribution of the paper to the literature is threefold. First, relying on a unique representative methodology to study food retail in a major city in the developing world, it documents the penetration strategy of modern retail in urban food markets. Second, using a battery of approaches rarely used for this topic, it illustrates price differences between modern and traditional markets comparing different survey methods (retailer and consumer exit interviews) as well as different analytical methods (hedonic pricing and propensity score matching methods). Third, unusual for a country in this (very early) stage of modern retail diffusion, food prices in modern retail are already found to be lower or at par with traditional retailers, for both processed staples and for fresh produce. However, the modern retail sector is 
yet unable to deliver quality, especially in the fresh produce sector, probably due to lack of proper food supply chain management and in-store handling.

The structure of the paper is as follows. In Section 2, we discuss the structure of food retail in general and the emerging modern retail sector, in India overall and in Delhi in particular. Section 3 gives an overview of the sampling strategy and some descriptive statistics. Section 4 discusses the empirical methodology. In Section 5, an overview is presented of the penetration of modern retail in food markets in Delhi. Section 6 compares food prices in modern retail with traditional markets. We finish with the conclusions in Section 7.

\section{TAXONOMY OF FOOD RETAIL IN DELHI}

\section{(a) Traditional retail}

A large number of players are active in the retailing of food in Delhi. They include the traditional informal (in Indian discussions often termed 'unorganized retail') sector, the cooperatives, the government-subsidized public distribution system, and modern retail. First, wetmarket traders, pushcarts as well as kirana ('mom-and-pop') stores make up the traditional informal sector. In wetmarkets, a number of small retailers of fruits and vegetables typically cluster together and sell their produce from a specific place during fixed hours of the day, often at the end of the afternoon and early evening. These markets are usually organized daily but the number of retailers might be larger on particular days of the week. Pushcarts typically roam around in residential areas and deliver fresh fruits and vegetables at the doorstep of different residences or stand in a public square or street corner in a specific regular place within the colony (the neighborhood). The pushcarts usually carry a single or a limited number of items. Customers may shop at these partly because of their locational advantages. Kirana stores are 
small "mom and pop" shops at fixed locations that carry a number of basic items, food" as well as non-food. The kirana stores are (typically) family-owned and are run mostly by family members, supplemented with some hired help (Kumar et al., 2008).

A second category of food retailer in India is the "cooperative modern retailer" associated with the cooperative sector. The Indian government has established public organizations to promote cooperative marketing, including the National Cooperative Development Cooperation and the National Dairy Development Board (NDDB) (Acharya, 2004). Acharya (1994) estimated that cooperatives handled about $10 \%$ of all marketed agricultural surplus in the country in the beginning of the 1990s. ${ }^{4}$ However, their importance seems to be declining over time. ${ }^{5}$ At present, cooperatives in Delhi appear especially important for the distribution of milk products (about 1000 Mother Dairy dairy retail kiosks) and fruits and vegetables (about 300 Safal Ltd produce shops). These booths are often centrally located within colonies on land allocated to them - hence rent-free-subsidized - by local authorities. Safal Ltd sources mainly from farmer associations' through a rural network of collection centers.

Third, parastatal marketing has in relatively recent years become an increasingly important food distribution channel in India, and this in contrast with most other developing countries that mostly saw increased withdrawal from governments over the past decade or more (World Bank, 2008). With the goal of assuring access to basic staples for the most vulnerable part of the population, food procurement is organized by the parastatal Food Corporation of India $(\mathrm{FCI})^{6}$ and the Public Distribution System (PDS) then retails these products, mainly rice and wheat (as well as two other essential commodities, sugar and kerosene oil) through Fair Price Shops (FPS). These items are distributed at a highly subsidized rate for poor consumers, through a system of household consumer cards, commonly known as ration cards. In the case of rice - 
one of the major products that we study -, Fair Price Shops sell at different prices for three different categories, i.e. Rs 3 for families that come under the 'Antodaya Anna scheme', Rs 6.15 for Below the Poverty Line (BPL) households and Rs 9 for Above the Poverty Line (APL) households (i.e. significantly below the market price, even controlling for the generally lower quality rice distributed by the FPS). Irrespective of household size and the category to which the family belongs, every household is entitled to $10 \mathrm{~kg}$ of subsidized rice under the present system. Fair Price Shops are usually not directly run by the government, but are given on lease to private individuals who get commissions based on the volume of off-takes from these shops. Some Fair Price Shops operate like any regular shop as they also sell other grocery items apart from the foodgrains allotted through the Public Distribution System. The total number of Fair Price Shops was estimated at 476,000 in rural and urban India in 2004, showing a gradual expansion over time (Rashid et al., 2008). ${ }^{7}$

\section{(b) Modern retail}

India is a latecomer in the global supermarket revolution (Reardon et al., 2003; World Bank, 2008). A first-phase development happened during the late nineties and was mostly based in southern India, focused on the middle class, and was started by the joint-venture between Spencer's and Hong Kong's regional multinational supermarket chain Dairy Farm International, to form Food World chain. This chain was soon followed by others that developed in the favorable conditions of Southern India in the second half of the 1990s, when the IT boom drove up incomes and generated investment capital. Reardon et al. (2008) argue that India's modern retail entered in the second stage, since 2001, what may be the fastest pace of supermarket diffusion in the world. They show that the sales of food/groceries by modern retailers were a mere 140 million USD in 2001 but had reached 5.8 billion USD by 2008. That implies an 
average annual nominal growth of $74 \%$ or a real growth of $65 \%$, though from a low base. ${ }^{8,9}$ Reardon et al. (2008) find, based on modern retailers' interviews, that some $80 \%$ of modern retail sales at this stage are from staples and processed foods, with fresh produce accounting for some $10-15 \%$ of sales (similar to modern retail in other developing countries). While growth has more recently seemingly come down, probably linked with the global recession, significant growth is however set to continue in the next years given the important investment plans, driven by fierce competition between these modern retailers. In 2008, plans announced by the main retail companies totaled investments of $\$ 33$ billion through 2010 .

\section{DATA}

\section{(a) Sample}

The sample for the survey in Delhi was set up as follows. First, eight representative food products were selected: tomato, onion, and potato in the vegetables category; apple and banana in the fruits category; and rice, atta (wheat flour), and mustard oil in the processed food category. These products were chosen based on their importance in the diet of the urban Indian and the presence of these products in the markets during the period of the survey. Second, the Municipal

Corporation of Delhi (MCD) has well defined divisions, suitable for our sampling strategy. ${ }^{10}$ The MCD is divided into 12 zones with each zone containing several wards. The MCD has 272 wards in total. Each ward has then several colonies inside it. For our sample, one ward was randomly selected in each of the 12 zones of the MCD.

Two types of surveys were implemented in each of the selected wards. First, a census of food retail outlets was conducted. If there were less than ten colonies (the smallest urban geographical unit) in the ward, all the colonies were covered in the census exercise. If there were 
more than ten colonies, ten colonies were randomly selected within the chosen ward. A census was done of all operating private modern retail outlets and wetmarkets where one of these eight products was sold. Five colonies were then randomly selected within these ten colonies. Within these five colonies, a census was conducted of all the other retail outlets (pushcarts, Safal outlets, Fair Price Shops, and kirana stores) that sold any of the eight products covered.

A survey of the retailers - focusing on their retailing practices of the selected products, the prices they charge, and relevant quality questions - was then conducted with the following agents: 1/ Private Modern retail. All modern retail outlets in these ten colonies were surveyed for all eight products; $2 /$ Wetmarket retailers. ${ }^{11}$ The two major wetmarkets were selected and a complete census was conducted of all the retailers in the wetmarket that were selling the five fruits and vegetables. Five wetmarket retailers were randomly selected for each product in each market; these retailers were interviewed; 3/ Pushcart retailers. In each of the five selected colonies, two pushcart retailers were interviewed for each of the five fruits and vegetables; 4/ Kirana (mom-and-pop) stores. Four shops were randomly selected and interviewed in each of the five selected colonies; 5/ Cooperative modern retail (Safal store). One store was randomly selected in the five colonies and interviewed; 6/ Consumer exit interviews. In each selected wetmarket, five customers that just purchased one of the five fruits and vegetables were randomly selected and exit interviews were conducted. Per ward and per product, we thus aimed to cover 20 traditional retailers, 10 consumers, 1 Safal outlet, and all private modern retails (for a maximum of 10 colonies). This survey was conducted during the period of February 16, 2009 to March 19, 2009.

At the end of March and the beginning of April, a second smaller survey was conducted in 6 of the 12 selected wards where retailers in each category were randomly selected and were 
asked about their turnover the day before. We also bought produce from traditional retailers to test the often heard hypothesis that they cheat in weighing, which would lead to biases in the price comparisons. During this second round, all Fair Price Shops were visited in the five selected colonies of each ward during regular opening hours. ${ }^{12}$ It was then noted if the shop was open. If the shop was open, rice qualities were noted. Additional information on the structural characteristics of the modern retail stores was also collected during this period.

\section{(b) Descriptive statistics}

Table 1 presents descriptive statistics for the sample of traditional retailers. Around 100 pushcart retailers and around 100 wetmarket retailers were interviewed for each fruit and vegetable product. Just over 200 kirana stores were interviewed for the processed products. We were unable to reach the targeted number of traditional retailers (240) for our sample as some colonies did not have enough traditional retailers in each category. The data show that there is clear specialization of the type of products sold by different retail outlets as kirana shops focus exclusively on processed food while pushcarts and wetmarkets distribute the fresh produce (Table 1).

Table 1 further shows that almost half of the traditional retailers use an electronic weighing scale. These are overwhelmingly the kirana stores. $20 \%$ do home delivery (especially the mobile pushcarts). $40 \%$ of the kirana stores report that they provide credit to some of their customers while none of the pushcarts or wetmarket traders says to do so. Note that this low rate of credit provision by traditional retailers is surprising given the conventional wisdom that the great majority of traditional retailers provide credit to customers. $5 \%$ and $31 \%$ of the traditional retailers do their business within 25 and 100 meters respectively of a modern retail outlet, 
indicating the spread of these modern outlets in Delhi but also showing their co-existence at close distances.

Between 120 and 140 exit interviews in the wetmarket were conducted for each fruit and vegetable product in the survey. Besides product and price characteristics, information on age, gender, and perceived income levels of customers was also noted. Table 1 shows that the average quantity bought by each customer in the last transaction was small, just over $1 \mathrm{~kg}$. Interestingly, all customers interviewed in the exit survey reported that they paid in cash for their recent purchase of fruits and vegetables.

Safal, the spinoff from the cooperative Modern Dairy, is generally put in the category of modern retail as it is organized as a chain of small shops, with common sourcing (Reardon et al. 2008), and with self-service by customers. However, in some analyses here, we treat it as a separate category which we then call 'cooperative-modern retail' and distinguish it from the other modern retail outlets, which are termed 'private-modern retail'. Safal was found to be present in all the wards that were surveyed. It was selling all the fruits and vegetables that were part of our survey. However, it did not distribute any of the processed foods. During the time of the survey, Safal started revamping their shops and products on offer and Safal shops started selling processed foods such as rice and mustard oil, using own or associated companies' brands. However, in the selected wards at the time of the survey, no such renovated Safal shops were yet found and they are thus not part of the survey.

The private-sector modern retail sample comprised 72 outlets. Modern retail in India uses a number of formats ranging from large hypermarkets to small neighborhood stores. However, given the density of the population in Delhi and the constraint of zoning laws, few hypermarkets were found in our sample wards. Few of the stores are situated within malls (Table 2). Most of 
the modern retail stores are relatively small (the average area is just below 800 square $\mathrm{ft}$ ) and are termed 'neighborhood store' format, a common format of modern retail in the dense cities of Asia (Reardon and Gulati, 2008). These modern outlets only have two and a half cash registers on average. Few of the outlets provide parking space that is specifically linked with the modern outlet $(7 \%)$ or provide annex services on their premises. Stores open early in the morning (7:20 am) and stay open late (9:40 pm). These stores carry largely food and groceries (including beverages): these products are estimated to represent almost $80 \%$ of the shelf space. ${ }^{13}$

As price analysis is a central theme in the analysis in this paper, we also report descriptive statistics on prices. Vegetables are the cheapest produce of the three categories with median prices ranging from $7 \mathrm{Rs} / \mathrm{kg}$ for potato to $18 \mathrm{Rs} / \mathrm{kg}$ for onion (Table 3 ). ${ }^{14}$ Fruits show high price diversity between the expensive imported apples and the much lower priced domestic bananas. Mustard oil is the most expensive processed food. Rice shows the highest price variation of all products as shown by its high coefficient of variation. The difference is partly explained by large price differences between basmati (the luxury type of rice) and other types of rice.

\section{EMPIRICAL METHODOLOGY}

\section{(a) Econometric methods}

Prices of products can vary widely because of differential quality, spatial, and temporal characteristics (Deaton, 1988). Two econometric techniques are relied upon that might explain variation of prices, i.e., hedonic price regression and propensity score matching. First, if we assume the marginal utility and the implicit price for each product characteristic to be constant, a hedonic price regression can be estimated where the food price is a function of attributes of the 
product (be it quality, spatial, or temporal characteristics). A simple model of the following form can then be estimated:

$$
p_{h}=\sum_{\mathrm{k}=0}^{\mathrm{N}} \beta_{\mathrm{kh}} X_{h}^{k}+v
$$

where $p_{h}$ is the price of the product $h, X^{k}{ }_{h}$ is the level of the attribute $k$ in product $h, \beta_{k h}$ the implicit price of attribute $k$, and $v$ a stochastic error term.

Second, in the propensity score matching (PSM) approach, a probit regression is first run where the dependent variable equals one if the food product is sold in the modern retail outlet and zero when sold in traditional retail outlets. Control variables include measures of quality and locational dummies. After the estimation of these probit models, a propensity score is obtained that allows for the matching treatment food products (those sold in modern outlets) and control products (those sold in traditional outlets). We use the common support approach to assure that the density of the treatment and comparison group overlap to a large extent. To ensure that the common support is fulfilled, only results are used that pass the balancing tests. We further match treatment and control groups by using the kernel PSM. ${ }^{15}$ Heckman et al. (1997) and Smith and Todd (2005) show the comparative benefits from these matching techniques. In this type of matching, the observations for food sold in modern retail outlets are matched with a weighted average of those in the control set, with greater weight given to the closest food product (Heckman et al., 1997).

\section{(b) Price measurement issues}

Three important issues in traditional food retail markets in India, as well as in a number of other developing countries, exist that might complicate the measurement of prices. They include bargaining, differential pricing, and cheating. First, prices are mostly not posted and bargaining 
might take place between the buyer and the seller before they settle on a price, especially for fresh produce. In the exit interviews that were conducted, we asked customers what prices were initially quoted to them and the prices that were ultimately settled on. We regress a ratio of these two prices (first quoted, finally paid, per customer) on variables that might potentially be associated with differential bargaining power (Table 4). First, we find that relatively little bargaining takes place in these wetmarkets and that the average difference between the final price and the initially quoted price amounts to only $3 \%$ (as shown by the size of the intercept). While at first glance this is surprising because it differs from some traditionally held views, on closer inspection it is not so as prices are usually loudly announced by the produce retailers in these markets, in our first-hand observations. Moreover, the presence of a large number of retailers dealing in the same product in the wetmarket might mean that the market is seemingly relatively competitive and transparent with little scope for bargaining. Second, none of the correlate variables (type of product, quantity bought, or income) turn out significant. Women customers are able to negotiate better as they obtain a reduction that is on average $4 \%$ lower than the initially quoted price.

Second, another issue that might complicate price measurement in traditional markets is that differential prices might be asked for different types of consumers (Chand, 2006, 2007). To understand the importance of this phenomenon, enumerators were asked to classify customers interviewed (in our study) after the purchase of one of the fruits and vegetables into low and high-income groups, based on a subjective evaluation of the appearance (for example, by looking at differences in the type of clothing) of the customer, presumably as a trader would do. We then test for differential pricing between them using the hedonic pricing approach. The results are reported in Table 5. We find that the consumers visually classed as poorer do pay lower prices, 
controlling for other confounding factors such as quality and location, in all five regressions, with differences ranging from $3 \%$ to $11 \%$. However, in only one out of the five cases, the difference is significant at the $5 \%$ significance level as measured by an F-test.

A potential third issue for price measurement is that it is often believed that traditional traders cheat customers with respect to weights. ${ }^{16}$ As all our prices are expressed in the local currency, rupees, per $\mathrm{kg}$ (except in the case of bananas where it is expressed in dozens) for the trader as well as the exit interview, a test was administered to assure that no systematic difference in weights existed between the traditional channel and modern retail. Produce samples were bought from traders in wetmarkets, pushcarts, and kirana stores and they were then carefully weighted with a calibrated electronic scale. The sample was set up as follows. One kilogram was bought for each of the four products (apples, potatoes, onions, and tomatoes) with a randomly selected trader in two of the wetmarkets in the six selected wards and with randomly selected pushcarts, one in each colony of the six selected wards. One kilogram of loose rice was also bought in a randomly selected kirana shop in each colony of the selected wards.

The results are reported in Table 6. Surprisingly, we find that weights in the traditional markets are slightly above the stated 1,000 grams by the traditional retailers. The average weight of the purchased produce was 1,005 grams and is statistically significantly higher than $1 \mathrm{~kg}$ as measured by a T-test (bottom of Table 6). However, as the difference is small (0.5\%), it will not create important bias in our price comparison between traditional and modern retail. When we compare the different products, we find that traditional traders tend to add extra weight especially for apples, possibly because of the larger unit weights of apples compared to the other products which make it more difficult to have exactly rounded weights. Table 6 also shows that retailers in the wetmarkets tend to deliver higher weights than pushcart retailers. T-tests for all 
products and for two products out of four reject equality of weights between wetmarkets and pushcarts. This is possibly driven by higher competitive pressures in wetmarkets where stalls are contiguous.

In summary, we find that bargaining might lead to slightly lower prices in wetmarkets and that richer consumers might pay slightly higher prices but we reject the hypothesis that traditional retailers cheat customers with weights. In our further analysis, we rely mostly on reported prices by traditional retailers. Enumerators were instructed to ask retailers for their practiced price of the day. Given that it is possible that some retailers reported the initial price and not the practiced price and that some enumerators might have given the impression to retailers of not being poor, the reported prices might in some cases be overestimated, although as noted above the effect of appearance of the customer in price formation was statistically weak. This caveat on price measurements in traditional markets should be kept in consideration in further analysis. Price measurement in modern retail on the other hand was straightforward given that modern retail outlets post prices, no bargaining takes place, and electronic scales are used by all of them.

\section{PENETRATION OF MODERN FOOD RETAIL}

\section{(a) Food retail share of modern retail}

Based on the census conducted in the representative wards and colonies, we are able to evaluate the importance of different types of food retail outlets in Delhi. Table 7 shows the number of outlets per colony and the share of different outlets in the total number in Delhi. Additionally, we asked about daily total sales of the products surveyed, from a sample of the 
traditional retailers, as well as Safal, Fair Price Shops, and from all the private-modern retail stores in our sample. That allows us to approximately estimate the share of different outlets in the total retail sales in Delhi of the particular food products surveyed.

The results show that the majority of the distribution of fruits and vegetables in Delhi is done through pushcart retailers and wetmarket retailers. Pushcarts represent between $56 \%$ and $64 \%$ of all the outlets of fruits and vegetables while the share in total retail of the wetmarket outlets varies from $30 \%$ to $39 \%$. Wetmarket vegetable retailers have however a much larger turnover than pushcarts and between $68 \%$ and $75 \%$ of the total quantity of vegetables are distributed by wetmarket retailers. The differences in turnover for fruits between pushcarts and wetmarket retailers are smaller and the shares for fruits of pushcarts and wetmarket retailers are of similar size. Kirana shops represent the great majority of turnover of retail of processed products, varying from $83 \%$ for rice to $96 \%$ for mustard oil.

Private-modern retail is currently still a relatively small player for food retail in Delhi. Depending on the product, it represents between $2.4 \%$ and $4.1 \%$ of the total number of retail stores in the city and between $3.0 \%$ and $6.5 \%$ of total turnover of these products. The share of private-modern retail is especially higher for the processed foods, varying from $4.3 \%$ to $6.5 \%$, than for the fresh produce, varying between 3.0\% and 4.2\%. Measured by number of outlets, cooperative-modern retail (Safal) is as important in the distribution of fruits and vegetables in Delhi as all private-modern retail combined. Their turnover is relatively lower for vegetables than for fruits though. For the latter, its food retail share is estimated at around $5 \%{ }^{17}$

The Fair Price Shops (FPS, the retail outlets of the PDS, the Public Distribution System) represent $14 \%$ of all outlets that sell rice in Delhi. In 2006, procurement by the government represented 26,9 million tons or $29 \%$ of the total production of that year (Reserve Bank of India). 
While PDS also reports similar amounts for PDS distribution (24.8 million tons in 2006), it is however not clear how good this system works and how well it is targeted (Umali-Deininger and Deininger, 2001; Dutta and Ramaswami, 2004; Rashid et al., 2008; Jha et al., 2007). To assess the importance of FPS in rice retailing in Delhi, we used a method of unannounced visits (e.g. Chaudhury et al., 2006; Kremer et al., 2005), where we visited all the FPS during regular opening times in the randomly selected wards. We found that only one-third of the FPS were open during the time of the survey (Table 7), despite our visit time being within the normal hours of such outlets. Those shops that were open realized significantly higher turnover than kirana shops. Some of the FPS that were open were found to be selling other products apart from those distributed through the PDS. These shops were also found to be more regular than the other. These results illustrate the challenges of the PDS to reach the poor in a regular and assured way. If they wanted to, the poor would only erratically be able to buy these food products at the subsidized prices in Delhi. These results are consistent with survey results of public service delivery in other sectors in India as well as other developing countries (e.g. Chaudhury et al., 2006; Kremer et al., 2005). Reasons given, during informal interviews with FPS managers and neighboring informants, for the closure of the shops related to lack of supplies, the limited number of ration cards that are distributed in urban areas, and leakage from the public distribution to private markets.

\section{(b) Start-up and location of modern retail}

Figure 1 shows the start-up dates of the private modern retail outlets in the sample. It illustrates the extent to which modern retail is a recent phenomenon in Delhi. $83 \%$ of the functioning outlets were started in the two years prior to the survey and almost half of the outlets began operations only in the year and a half before the survey. These results demonstrate the 
speed at which modern retail has obtained market share as the number of modern food retail outlets has on average more than doubled annually in the past three years, though from a low base. The speed of the roll-out in Delhi even came down significantly in months prior to the survey due to the closure of Subhiksha shops, which was one of the biggest modern retailers in Delhi. Reardon et al. (2008) thus argue that the roll-out of modern retail in India might be one of the fastest in history. Delhi might also have shown higher growth rates as it was relatively late compared to some major southern cities such as Hyderabad and Bangalore where the recent diffusion of modern retail started in India.

Moreover, the locational distribution of modern retail in Delhi runs contrary to expectation. Our expectation had been that modern retail outlets would be focused in the richer neighborhoods of the city, as has been found in other retailer settings in the early-stage of modernization in other developing countries (World Bank, 2008; Traill, 2006). Rather, we find in Delhi no strong and significant relationship between the number of modern retail outlets and a measure of the real estate value of the colony: none of coefficients come out significant in a (non-reported) tobit model where the dependent variable is the number of modern retail outlets in the colony. ${ }^{18}$ This seems to indicate that, in the case of Delhi, modern retail stores have spread in this phase of the roll-out in equal measure to the rich and poor neighborhoods of the city. This seems driven by different factors. First, both richer and poorer residents live "downtown" in Delhi, and modern retail has worked to penetrate the dense city with chains of small format stores mixed with occasional larger format stores. Second, in many richer residential areas, there are more stringent laws that regulate the operation of businesses, slowing down the spread of modern retail to these areas. Third, modern retail sells as cheap as or cheaper than traditional outlets (as seen in the next section) and thus might already cater to some poorer residents. 
Fourth, given higher population densities and lower rental rates, a major cost in the operation of modern retail outlets in Delhi, and given that they are already selling at relatively lower prices modern retail has profit incentives to not only focus on richer areas.

\section{(c) Products on offer in modern retail}

In Table 8, we compare diversity of types of each product (such as types of rice) as well as produce quality in modern versus traditional outlets. As expected, intra-product diversity is much higher in modern retail than in traditional outlets. The number of rice varieties that are for sale in modern retail is on average 9.15 versus only 4.12 in traditional retail outlets. Similar numbers for other processed foods as well as fresh produce show up but to a lesser extent.

We expect that, per product, modern retail outlets will have a higher share of the intraproduct diversity devoted to higher grades (defined here as 'quality') of the product. While this has not been examined in India, one finds for example in Vietnam that modern retailers have a higher share (in their product lines for rice) of higher quality rice (Figuié and Moustier, 2009). Our findings for Delhi confirm that expectation. In the case of rice, modern retail focuses almost exclusively ( $93 \%$ of rice products on offer) on the higher-quality basmati rice. In the traditional markets, basmati rice is less than $50 \%$ of the rice on offer: $19 \%$ is parmal rice (a long-grained rice, second in quality after Basmati), and the rest, 33\%, is non-parmal and non-basmati rice.

Similarly, we started with the expectation that produce quality is higher in modern retail outlets than traditional ones. This expectation was based on: (1) the scant prior research available (for example, Deodhar et al. (2006) found that $41 \%$ of the apples offered for sale in modern outlets in selected cities in India are the higher-grade imported apples compared to only $16 \%$ in traditional retail outlets); (2) the oft-repeated assertion in the Indian press and debate (see one of many examples, India Today (2007)); (3) evidence from other countries (e.g. Minten and 
Reardon, 2008). To evaluate this expectation, we selected main indicators of quality of each produce product and report, based on our enumerators' trained-observation and inventory of the qualities of each product, the percentage of the produce on offer in that quality category (Table 8). ${ }^{19}$ Surprisingly, the quality of fresh produce is found to be significantly worse in modern retail than in traditional outlets, and this for all the produce products in the sample. We find that the percentage of produce that belongs to the best category is between $36 \%$ and $17 \%$ lower in modern retail.

Compared to the roll-out of modern retail in other emerging economies, modern retail in India has moved surprisingly fast into fresh produce; the normal global pattern is that modern retail starts with processed foods and then over time gradually moves into fresh produce; this is the case in developing countries as well as historically in the US for example (Reardon and Timmer, 2007). It seems that the rapid roll-out of the offer of fresh produce in retail in India (tiny in its share in the overall market but already a limited but important section in the modern retail outlets) has not been matched by development of the supply chain and in-store handling (Reardon et al., 2008).

Another important difference in product inventory between traditional and modern retail is the share of labeled products on offer (Table 8 ). While $88 \%$ of the rice sold in modern retail is branded, this is only $31 \%$ in the case of traditional outlets. In the case of wheat flour (atta) and mustard oil, modern retail offers exclusively branded products. This compares to $70 \%$ and $78 \%$ branded products in traditional retail for atta and mustard oil respectively. Modern retail has also started with labeling (of which some is branding, particularly on imported apples) of fruits. 19\% and $57 \%$ of their apples and banana on sale were labeled. . The traditional outlets sell a significantly lower percentage of labeled fruit. 


\section{FOOD PRICES AND MODERN RETAIL}

\section{(a) Simple pair-wise comparisons}

To conduct the price comparison analysis between modern and traditional retail, we start with a simple pair-wise comparison - through the use of a t-test - of the product prices gathered from pushcarts, wetmarkets, and kirana shops and compare these with prices in modern retail ${ }^{20}$ (Table 9). To improve comparability, we create different categories for branded and non-branded rice and treat them as separate products in our analysis below. We find that for 8 out of the 14 product combinations, modern retail is significantly less expensive; for 3 out of 14, prices are at par; and for 3 out of 14, modern retail is significantly more expensive. Prices are higher in modern retail for apple compared to wetmarkets as well as pushcarts. Unbranded rice is also more expensive in modern retail.

The price differences between traditional and modern retail can be quite substantial. For example, while tomatoes are $20 \%$ less expensive in modern retail compared to pushcarts, the situation is the reverse for apples. In the case of fresh produce, modern retail is significantly less expensive than pushcarts in 4 out of 5 cases compared to only 2 out of 5 in the case of wetmarket retailers. Modern retail is thus a seemingly significantly cheaper alternative when compared to pushcarts in particular. However, these pushcarts also deliver services that modern retail do not deliver, such as daily home delivery of small quantities.

A large part of the difference in the pair-wise comparisons can potentially be explained by confounding factors. In the next sections, we will subject the modern versus traditional price comparison to different types of empirical analysis, using a battery of controls related to the 
quality of the product and to the location, to different survey techniques, and to changes in definitions of modern and traditional retail.

\section{(b) Hedonic pricing}

As discussed in the empirical methodology section, a hedonic price regression methodology is used where the retail price per kilogram is regressed on categorical variables for the type of retail outlet, the quality of the product, a ward categorical variable, and a wealth variable of the colony. Objective quality characteristics were developed for each product. ${ }^{21}$ As we rolled out the survey by ward - we went with the team for two days in a ward -, controlling with a ward variable controls concurrently with time and locational variation. We further use a wealth indicator per colony to control for potential demand factors. A dummy variable for labeled produce was also included in the case of fruits and processed products.

While simple pair-wise comparisons of prices of fresh produce show that in 6 out of 10 regressions, modern retail is less expensive, this difference exists only in 4 out of 10 cases in the hedonic price regression (Table 10, version 1). This indicates to what extent the price difference is partly explained by lower quality in modern retail for fresh produce. Even in a hedonic model, apple in modern retail stays more expensive compared to pushcarts. However, prices are not significantly different compared to wetmarkets. We further test to what extent changes in the definition of modern retail (by excluding the data from the cooperative-modern retail chain, Safal), and the disaggregation of the results of exit interviews and trader reported prices change the results (Table 10, version 2). In most cases, F-tests on the difference of modern retail with traditional markets indicate that results are not significant or show no consistent pattern of significantly higher or lower price. We thus conclude in the case of fresh produce that modern retail is mostly at par with traditional markets, when we control for quality. It is also interesting 
to note that in none of the tests, prices in private-sector modern retail differ significantly from those of the cooperative-modern retail chain Safal. In Table 11, results are shown from the hedonic price regressions for processed foods. In all three cases, private-sector modern retail is shown to be significantly cheaper than kirana shops.

\section{(c) Propensity Score Matching (PSM)}

To start the analysis using Propensity Score Matching, probit regressions were run with dummy variables of food sold in supermarket coded as 1 , and food sold in traditional retail outlets coded as 0 , as dependent variables. The controls include measures for quality, labeling, quantities sold, ward dummy variables, wealth dummy variables per colony, and an intercept. Using the results of these regressions for the construction of a propensity score, Table 12 then shows the Propensity Score Matching impact estimates on prices for all eight products comparing modern retail (treated) with traditional markets (control). We present the results of the unmatched sample and the average treatment effect for the treated (ATT).

When we match control and treatment groups with similar characteristics in the category of fresh produce, one vegetable is significantly less expensive in supermarkets (tomato). The other prices of fresh produce are found to be at par. When we look at the control groups for fresh produce in traditional markets, in all cases prices go down from the unmatched sample to the matched sample, indicating the lower qualities that are offered in modern retail. For the three processed products, two products are more expensive and one product is less expensive in unmatched samples. However, we find that modern retail is always significantly less expensive for similar products, i.e. the matched samples, as shown by the large t-values for the ATT. The price differences of similar processed products in modern compared to traditional retail (kirana 
stores) varies from $4 \%$ lower in modern retail (compared to kirana stores) for mustard oil, to $6 \%$ for atta, and to $11 \%$ for rice.

In summary, we find often large quality and/or price differences between traditional and modern retail. In simple pair-wise comparisons, fresh produce is often less expensive in modern retail but these effects mostly disappear when we control for quality as done in the hedonic pricing methods and the propensity score matching. Processed foods shows ambiguous results in the pair-wise comparison but after controlling for confounding factors, all products are significantly cheaper in modern retail no matter which method is used.

\section{CONCLUSIONS}

Using unique data from a large-scale survey on food retailing in Delhi, a context of the initial stages of modern retail diffusion, several important findings emerge.

First, food is retailed by a large number of players that deliver different types of services. These players include traditional retailers (pushcart retailers, kirana shops, and wetmarket retailers), cooperative-modern retail chains of small shops (e.g. Safal), public sector distribution system chain stores (Fair Price Shops), and private-sector modern retail chains. Wetmarkets are most important in the supply of vegetables; pushcart retailers are as important as wetmarkets for fruits; and mom-and-pop (kirana) stores distribute the large majority of processed foods.

Second, modern retail is rolling out at a very fast pace. While starting from a low base, the number of modern retail stores in Delhi has, on average, more than doubled in each of the past three years. In that time span, private-sector modern retail has captured up to $6.5 \%$ of the processed food markets and about $3-4 \%$ of the fresh produce market, much higher than estimates 
of the national share of modern retail in India, and despite modern retail's penetration being in its infancy in india, our results show that its food sales are already $41 \%$ as important as food and agricultural exports from India in value terms. ${ }^{22}$ The rapidity of the even initial penetration of fresh produce retail is a unique case in studies of modern retail in developing countries.

Third, modern retail is shown to offer more labeled food products and more intra-product diversity than traditional markets. Moreover, it supplies similar products at the same or lower prices than traditional retail. This is a surprising and unconventional result compared to evidence for other early modern-retail development situations elsewhere in the developing world. However, while modern retail also offers lower prices for fresh produce, it is yet unable to deliver quality and the low price effect largely disappears when we control for quality.

Fourth, while government intervention in food markets might have contributed to improved access to food for some of the poor, our results indicate that the government is not able to assure access to cheap food in a regular way or for all of them as only one-third of the Fair Price Shops that distribute subsidized rice were found to be open during regular opening hours.

While modern retail sells food at relatively low prices, the poor seem to benefit less than as fully as the results imply in these early stages from the modern retail roll-out for several reasons. ${ }^{23}$ First, we find that the poor are already able to negotiate slightly lower prices with traditional retailers as compared to richer customers. If they would switch to modern retail, they will gain slightly less from the price differences that exist between modern and traditional outlets. Second, while modern retail can deliver processed products cheaper than traditional retail, it however tends to focus on offering labeled or branded products, which are significantly more expensive and less sought by the poorer part of the population; this at present reduces modern retail's 'reach' in the term of Goldman (1974). Third, modern retail does mostly but not 
exclusively sell packaged products, while loose products (such as atta) are especially bought by the poorer people as it allows them to buy in smaller quantities. On the other hand, while modern retail tends generally (elsewhere in the developing world) to first locate in relatively better-off areas, we do not find evidence of this in our case study of Delhi and the poor do not seem excluded from modern retail access because of spatial concerns.

By controlling urban food price inflation as well as by assuring a regular supply of food, modern retail might become an important, and sustainable, contributor to improved food security. There are however still significant constraints to further roll-out in India. First, while modern retail is globally able to put in place more efficient food supply chains and might thus reduce costs in the value chains, it might however be in a disadvantaged cost position in India in particular due to high rental rates, even for international norms, in the big cities. Small mobile retailers that modern retail has to face in the fresh produce market do not face these costs. These smaller retailers might also deliver services that modern retail does not deliver, such as daily home delivery in small quantities. Second, modern retail is hampered by regulatory issues given inflexible labor laws for formal enterprises, the constraints on direct sourcing from the farmers in some states, as well as the limit on foreign investments in food retail. Given the need of better technologies in the organization of supply chains, there might be significant benefits from more exposure to such technologies, possibly through increased FDI in this area.

While the price and quality results differ from most conventional wisdom in India and from extant evidence from other countries in an early stage of modern retail diffusion, it is beyond the scope of the paper to study why these price and quality results occur. This becomes an agenda for further research. The hypotheses to test appear to be: (1) whether modern retail has better procurement systems and supply chain management, or is allowing some foods to be loss- 
leaders to attract enough visitors (create 'footfall') and to compete with traditional retail, or both; (2) whether modern retail has poor handling or inventory management and in-store handling, or insufficient incentives to suppliers to provide better grades, explaining the puzzle of modern retailers having lower quality produce in various items; (3) whether government Fair Price Shops lack access to supplies or whether it is government mismanagement, to explain the very low rate of accessibility to poor consumers. 


\section{REFERENCES}

Asfaw, A. (2007). Supermarket purchases and the dietary patterns of households in Guatemala, Discussion Paper 696, Washington: International Food Policy Research Institute.

Chand, R. (2007). Marketing and trade policies in a globalizing world. Indian Journal of Agricultural Marketing, 21(3):20-30

Chand, R. (2006). Agriculture markets in India: Implications for competition. In Mehta P.S. (ed.), Towards a Functional Competition Policy for India, Academic Foundations, Delhi, $139-151$.

Chaudhury, N., Hammer, J., Kremer, M., Muralidharan, K., Rogers, F.H. (2006). Missing in Action: Teacher and Health Worker Absence in Developing Countries. Journal of Economic Perspectives, 91-116.

Chengappa, P.G. (2006). Evolution of Food Retail Chains: Evidence from South India. Paper presented at IFPRI-IEG workshop, September 2006, Delhi, India.

Deaton, A. (1988). Quality, Quantity and Spatial Variation of Price. American Economic Review 78(3): 418-430.

Deodhar, S.Y., Landes, M., Krissoff, B. (2006). Prospects for India's Emerging Apple Market, United States Department of Agriculture, FTS-391-01.

D’Haese, M. and Van Huylenbroeck, G. (2005). The Rise of Supermarkets and Changing Expenditure Patterns of Poor Rural Households: Case Study in the Transkei Area, South Africa. Food Policy, 30:97-113.

Dutta, B. and Ramaswami, B. (2004). Reforming food subsidy schemes: Estimating the gains from self-targeting in India. Review of Development Economics, 8(2): 309-324. 
Fafchamps, M., Vargas-Hill, R., and Minten, B. (2008). Quality Control in Non-Staple Food Markets: Evidence from India. Agricultural Economics, vol. 38, 251-266.

Figuié, M., Moustier, P. (2009). Market appeal in an emerging economy: Supermarkets and poor consumers in Vietnam. Food Policy, 34(2): 210-217.

Goldman, A. (1974). Outreach of consumers and the modernization of urban food retailing in developing countries. Journal of Marketing 38(4): 8-16.

Gulati, A. and T. Reardon (2008). "Organised retail and food price inflation - Opening the 'Black Box"” Hindu Business Line, May 24.

Hawkes, C. (2008). Dietary implications of supermarket development: A global perspective. Development Policy Review. 26(6): 657-692.

Heckman, J., Ichimura, H., Todd, P. (1998). Matching as an econometric evaluation estimator, The Review of Economic Studies, 65(2): 261-294.

Ho, S.-C. (2005). Evolution versus Tradition in Marketing Systems: The Hong Kong FoodRetailing Experience. J. Public Pol. and Marketing, 24(Spring): 90-9.

India Today. (2007). Veggie Mart Turns Smart. April 2. No paging. http://www.indiatoday.com/itoday/20070402/business.html

Joseph, M., Soundararajan, N., M. Gupta, S. Sahu. (2008). Impacts of Organised Retailing on the Unorganised Sector, Delhi: ICRIER.

Kremer, M., Muralidharan, K., Chaudhury, N., Hammer, J., Rogers, F.H. (2005). Teacher Absence in India: A Snapshot. Journal of the European Economic Association, 3 (2-3): 658-667.

Kumar, V., Patwari, Y., Ayish, H.N. (2008). Organized food retailing: A blessing or a curse, Economic \& Political Weekly, May 17, 67-75. 
Minot, N. and Roy, D. (2007). Impact of high-value agriculture and modern marketing channels on poverty: An analytical framework, Washington: IFPRI, mimeo.

Minten, B. (2008). The food retail revolution in poor countries: Is it coming or is it over? Economic Development and Cultural Change, 56(4): 767-789.

Minten, B. and Reardon, T. (2008). Food prices, quality and quality's pricing in supermarkets versus traditional markets in developing countries. Review of Agricultural Economics, 30(3): 480-490.

Neven, D., T. Reardon, J. Chege, and Wang, H. (2006). "Supermarkets and Consumers in Africa: The case of Nairobi, Kenya," Journal of International Food \& Agribusiness Marketing. 18 (1/2): 103-123.

Rashid, S., Gulati, A., Cummings, R. (2008). From Parastatals to Private Trade: Lessons from Asian Agriculture. Baltimore: John Hopkins University Press.

Reardon, T. and A. Gulati. (2008). The Rise of Supermarkets and Their Development Implications: International Experience Relevant for India. IFPRI Discussion Paper 007, February. Washington: IFPRI.

Reardon, T., A. Gulati, and B. Minten. (2008). Supermarkets and Agrifood System Development in India: Innovations in Procurement that Link Small Farmers to Modernizing Markets. Paper presented 28 July at the American Agricultural Economics Association Annual meetings, in Orlando, at the Organized Symposium "The Changing Face of Agricultural and Food Marketing in India: Linking Farmers with Markets”.

Reardon, T. C.P. Timmer, C.B. Barrett, and J.A. Berdegué, (2003). The Rise of Supermarkets in Africa, Asia, and Latin America. American Journal of Agricultural Economics. 85(5): $1140-1146$. 
Reardon, T. and C.P. Timmer (2007). “Transformation of Markets for Agricultural Output in Developing Countries Since 1950: How Has Thinking Changed?” chapter 55 in R.E. Evenson, and P. Pingali (eds). Handbook of Agricultural Economics, 3: Agricultural Development: Farmers, Farm Production and Farm Markets. Amsterdam: Elsevier Press: 2808-2855.

Swinnen, J. (editor) (2007). Global Supply Chains, Standards and the Poor. Wallingford: CABI Publishing.

The Hindu Business Line. (2005). Amendments to Consumer Protection Act likely, The Hindu Business Line, September 26, no paging, http://www.thehindubusinessline.com/2005/09/27/stories/2005092702340800.htm

Traill, B. (2006). The Rapid Rise of Supermarkets? Development Policy Review. 24(2): 163-174.

Umali-Deininger, D.L., Deininger, K. (2001). Towards greater food security for India's poor: Balancing government intervention and private competition. Agricultural Economics, $25: 321-335$.

World Bank (2008). World Development Report, Agriculture for Development, Washington: World Bank. 
Table 1: Descriptive statistics of the sample for traditional retail

\begin{tabular}{|c|c|c|c|}
\hline \multicolumn{2}{|c|}{ Item } & Unit & Statistics \\
\hline \multicolumn{4}{|c|}{ Traditional retailers } \\
\hline Apples & Pushcarts & number of obs. & 110 \\
\hline Apples & Wet market/cluster & number of obs. & 111 \\
\hline Banana & Pushcarts & number of obs. & 115 \\
\hline Banana & Wet market/cluster & number of obs. & 98 \\
\hline Potatoes & Pushcarts & number of obs. & 121 \\
\hline Potatoes & Wet market/cluster & number of obs. & 101 \\
\hline Onions & Pushcarts & number of obs. & 106 \\
\hline Onions & Wet market/cluster & number of obs. & 100 \\
\hline Tomatoes & Pushcarts & number of obs. & 109 \\
\hline Tomatoes & Wet market/cluster & number of obs. & 108 \\
\hline Mustard oil & Kiranashops & number of obs. & 219 \\
\hline Atta & Kiranashops & number of obs. & 219 \\
\hline Rice & Kiranashops & number of obs. & 212 \\
\hline \multicolumn{2}{|c|}{ Retailers using electronic weighting scale } & $\%$ & 45 \\
\hline Retailers tha & livery for some customers & $\%$ & 18 \\
\hline \multicolumn{4}{|c|}{ Retailers that provide credit to some customers } \\
\hline & Pushcarts & $\%$ & 0.2 \\
\hline & Wet market/cluster & $\%$ & 0.0 \\
\hline & Kiranashops & $\%$ & 40.2 \\
\hline \multicolumn{2}{|c|}{$\%$ of retailers that sell within 25 meters of modern retail } & $\%$ & 5 \\
\hline \multicolumn{2}{|c|}{$\%$ of retailers that sell within 100 meters of modern retail } & $\%$ & 31 \\
\hline \multicolumn{4}{|c|}{ Exit interviews customers } \\
\hline \multicolumn{2}{|c|}{ Apple buyers } & number of obs. & 144 \\
\hline \multicolumn{2}{|c|}{ Banana buyers } & number of obs. & 129 \\
\hline \multicolumn{2}{|c|}{ Potato buyers } & number of obs. & 139 \\
\hline \multicolumn{2}{|c|}{ Onion buyers } & number of obs. & 122 \\
\hline \multicolumn{2}{|c|}{ Tomato buyers } & number of obs. & 140 \\
\hline \multicolumn{2}{|c|}{ Quantity bought } & kgs & 1.26 \\
\hline \multicolumn{2}{|c|}{ Age } & years & 37 \\
\hline \multicolumn{2}{|c|}{ Female customers } & $\%$ & 50 \\
\hline \multicolumn{2}{|c|}{ Low income consumers } & $\%$ & 48 \\
\hline \multicolumn{2}{|c|}{ Paid in cash } & $\%$ & 100 \\
\hline
\end{tabular}


Table 2: Descriptive statistics of the modern retail sample

\begin{tabular}{llr}
\hline Item & Unit & \multicolumn{1}{c}{ Statistics } \\
\hline Outlets & number of obs. & 72 \\
Area (square foot) & mean & 797 \\
Importance of food and groceries & $\%$ & 78 \\
Opening time (am) & mean & $7: 20$ \\
Closing time (pm) & mean & $9: 40$ \\
Number of cash registers & mean & 2.5 \\
Stand alone modern retail & $\%$ & 94 \\
Entrance on parking lot & $\%$ & 21 \\
Parking space available exclusively for supermarket & $\%$ & 7 \\
Annex service on premises & $\%$ & 14 \\
\hline
\end{tabular}

Table 3: Price variation

\begin{tabular}{lrrrrr}
\hline & $\begin{array}{c}\text { Number of } \\
\text { observations }\end{array}$ & Mean & Median & $\begin{array}{r}\text { Standard } \\
\text { deviation }\end{array}$ & $\begin{array}{c}\text { Coefficient } \\
\text { of variation }\end{array}$ \\
\hline Vegetables & & & & & \\
Tomato & 496 & 11.39 & 10.70 & 3.11 & 0.27 \\
Potato & 531 & 7.19 & 7.00 & 2.35 & 0.33 \\
Onion & 475 & 17.65 & 18.00 & 5.01 & 0.28 \\
Fruits & & & & & \\
Apple & 673 & 79.31 & 78.00 & 27.98 & 0.35 \\
$\quad$ Imported & 142 & 120.75 & 120.00 & 17.44 & 0.14 \\
$\quad$ Local & 531 & 68.23 & 65.00 & 18.13 & 0.27 \\
Banana & 505 & 24.39 & 24.00 & 5.61 & 0.23 \\
Processed food & & & & & \\
Rice & 1418 & 47.85 & 38.00 & 29.52 & 0.62 \\
$\quad$ Basmati & 921 & 60.63 & 56.00 & 28.32 & 0.47 \\
$\quad$ Non-parmal & 307 & 23.91 & 22.00 & 12.69 & 0.53 \\
$\quad$ Parmal & 175 & 23.13 & 22.00 & 5.52 & 0.24 \\
Atta & 823 & 16.99 & 17.00 & 2.17 & 0.13 \\
Mustard oil & 658 & 79.82 & 81.00 & 10.46 & 0.13 \\
\hline
\end{tabular}


Table 4: Correlates initially quoted and final prices paid by consumers

(Dep. var. $=$ final/initial quoted price*100)

\begin{tabular}{llrr}
\hline Regressors & Unit & Coefficient & \multicolumn{1}{c}{ t-value } \\
\hline quantity & $\log ($ value & -0.063 & -0.120 \\
income & 1=poor & -0.482 & -1.090 \\
gender & 1=female & -1.230 & $\mathbf{- 2 . 7 4 0}$ \\
age & years & -0.001 & -0.030 \\
default=tomato & & & \\
potato & 1=yes & 1.088 & 1.390 \\
onion & 1=yes & 0.313 & 0.410 \\
banana & 1=yes & 1.274 & 1.580 \\
apple & 1=yes & 1.627 & 1.370 \\
Intercept & & 97.017 & $\mathbf{5 7 . 9 6 0}$ \\
\hline Number of observations & & 682 & \\
F( 8, 673) & & 1.92 & \\
Prob > F & & 0.054 & \\
R-squared & & 0.023 & \\
Root MSE & & 5.756 & \\
\hline
\end{tabular}

Table 5: Price differences between rich and poor consumers, based on hedonic price regressions

\begin{tabular}{|c|c|c|c|c|c|}
\hline & $\begin{array}{c}\text { Number of } \\
\text { observations }\end{array}$ & Coefficient* & t-value* & F-test & Prob $>F$ \\
\hline \multicolumn{6}{|l|}{ Vegetables } \\
\hline Tomato & & & & 2.010 & 0.157 \\
\hline Poor consumers & 78 & -0.150 & -3.220 & & \\
\hline Rich consumers & 61 & -0.058 & -1.070 & & \\
\hline Potato & & & & 0.910 & 0.340 \\
\hline Poor consumers & 72 & 0.119 & 2.240 & & \\
\hline Rich consumers & 68 & 0.179 & 4.360 & & \\
\hline Onion & & & & 3.870 & 0.050 \\
\hline Poor consumers & 68 & -0.174 & -5.350 & & \\
\hline Rich consumers & 64 & -0.067 & -1.560 & & \\
\hline \multicolumn{6}{|l|}{ Fruits } \\
\hline Banana & & & & 0.700 & 0.405 \\
\hline Poor consumers & 58 & -0.138 & -3.620 & & \\
\hline Rich consumers & 72 & -0.093 & -2.510 & & \\
\hline Apple & & & & 1.080 & 0.300 \\
\hline Poor consumers & 55 & -0.017 & -0.680 & & \\
\hline Rich consumers & 89 & 0.015 & 0.580 & & \\
\hline
\end{tabular}

*: Coefficients out of pooled hedonic pricing regression where $\log ($ price $)=f($ retail outlets, quality, location) 
Table 6: Results weighing survey of $1 \mathrm{~kg}$ of produce in different market settings

\begin{tabular}{|c|c|c|c|c|c|c|c|}
\hline \multirow[t]{2}{*}{ Item } & \multirow{2}{*}{$\begin{array}{l}\text { Type of } \\
\text { retailer }\end{array}$} & \multirow{2}{*}{$\begin{array}{c}\text { Number of } \\
\text { observations }\end{array}$} & \multirow{2}{*}{$\begin{array}{c}\text { Mean } \\
\text { in grams }\end{array}$} & \multirow{2}{*}{$\begin{array}{c}\text { Standard } \\
\text { error }\end{array}$} & \multirow{2}{*}{$\begin{array}{l}\text { Type } \\
\text { t-test }\end{array}$} & \multicolumn{2}{|c|}{ T-test } \\
\hline & & & & & & t-value & $\operatorname{Pr}(|\mathrm{T}|>|\mathrm{t}|)$ \\
\hline Tomato & All & 42 & 1003.69 & 2.97 & (1) & 1.241 & 0.222 \\
\hline Tomato & Pushcarts & 30 & 1002.17 & 3.70 & (1) & 0.586 & 0.562 \\
\hline Tomato & Wet market & 12 & 1007.50 & 4.86 & (1) & 1.544 & 0.151 \\
\hline Tomato & & & & & (2) & -0.806 & 0.425 \\
\hline Potato & All & 42 & 1002.48 & 3.86 & (1) & 0.642 & 0.525 \\
\hline Potato & Pushcarts & 30 & 996.33 & 3.98 & (1) & -0.922 & 0.364 \\
\hline Potato & Wet market & 12 & 1017.83 & 7.74 & (1) & 2.304 & 0.042 \\
\hline Potato & & & & & (2) & -2.704 & 0.010 \\
\hline Onion & All & 42 & 1004.33 & 3.81 & (1) & 1.137 & 0.262 \\
\hline Onion & Pushcarts & 30 & 999.97 & 4.95 & (1) & -0.007 & 0.995 \\
\hline Onion & Wet market & 12 & 1015.25 & 3.58 & (1) & 4.259 & 0.001 \\
\hline Onion & & & & & (2) & -1.866 & 0.070 \\
\hline Apple & All & 42 & 1016.50 & 3.37 & (1) & 4.893 & 0.000 \\
\hline Apple & Pushcarts & 30 & 1010.27 & 2.95 & (1) & 3.483 & 0.002 \\
\hline Apple & Wet market & 12 & 1032.08 & 7.76 & (1) & 4.135 & 0.002 \\
\hline Apple & & & & & (2) & -3.244 & 0.002 \\
\hline Rice & Shops & 30 & 995.13 & 2.91 & (1) & -1.668 & 0.106 \\
\hline All products & All & 198 & 1004.99 & 1.61 & (1) & 3.090 & 0.002 \\
\hline All products & Pushcarts & 120 & 1002.18 & 2.10 & (1) & 1.087 & 0.279 \\
\hline All products & Wet market & 48 & 1018.17 & 3.29 & (1) & 5.518 & 0.000 \\
\hline All products & & & & & (2) & -4.208 & 0.000 \\
\hline
\end{tabular}

(1): T-test if weight is different from 1000

(2): T-test if weight on wet markets is different from pushcarts 


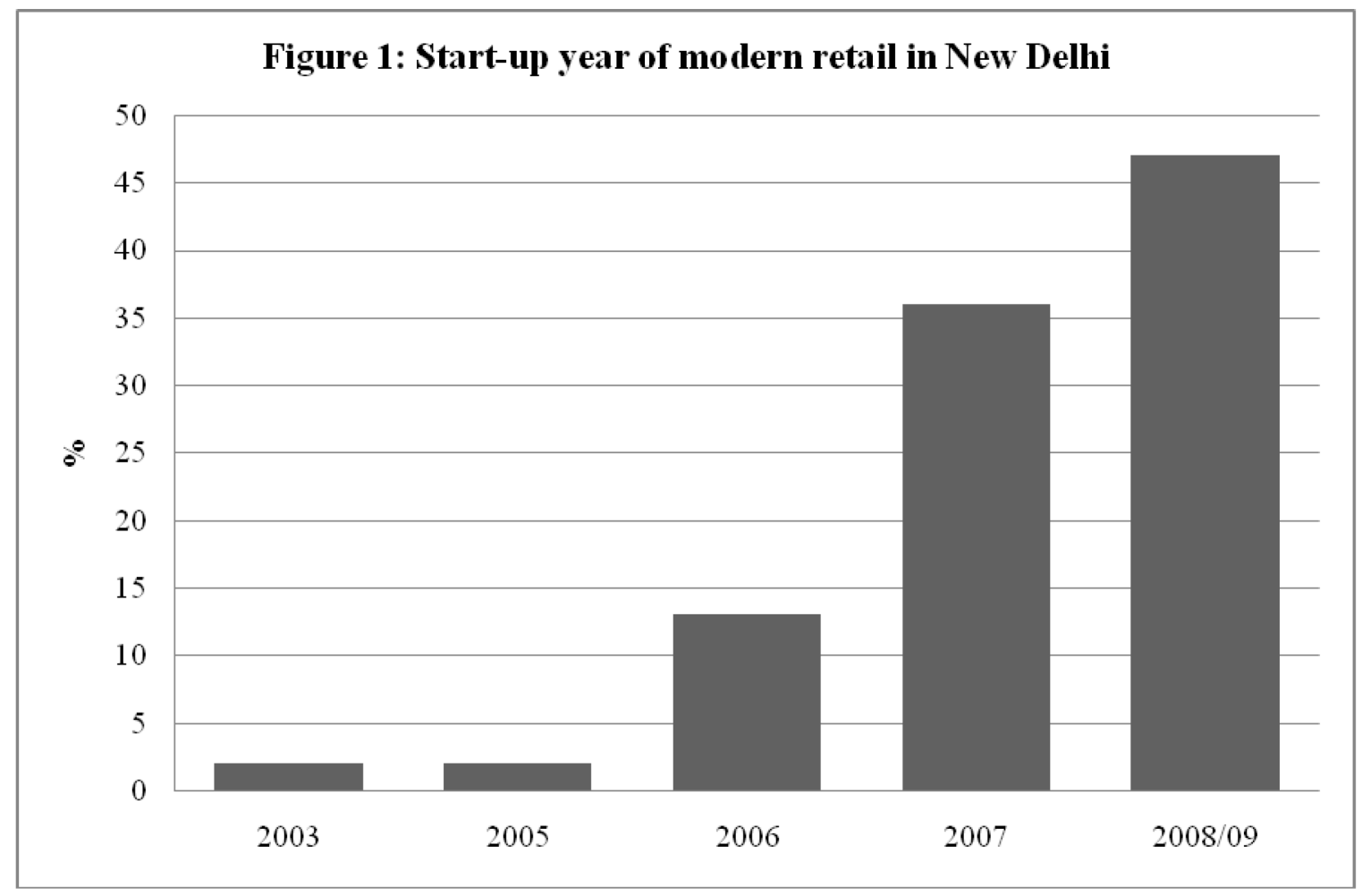


Table 7: Importance of different food outlets in New Delhi

\begin{tabular}{|c|c|c|c|c|c|c|}
\hline & \multirow[b]{2}{*}{ Unit } & \multicolumn{5}{|c|}{ Retail food outlets } \\
\hline & & Wetmarkets & Pushcarts & Safal & Modern retail & Total \\
\hline \multicolumn{7}{|l|}{ Vegetables } \\
\hline Tomato & Number/colony & 3.3 & 5.0 & 0.3 & 0.3 & 8.9 \\
\hline Tomato & $\%$ outlets & 37.6 & 56.0 & 3.4 & 3.1 & 100.0 \\
\hline Tomato & $\%$ turnover & 74.6 & 20.5 & 1.9 & 3.0 & 100.0 \\
\hline Potato & Number/colony & 4.0 & 5.7 & 0.3 & 0.3 & 10.2 \\
\hline Potato & $\%$ outlets & 38.7 & 56.0 & 2.6 & 2.7 & 100.0 \\
\hline Potato & $\%$ turnover & 73.0 & 21.3 & 2.3 & 3.3 & 100.0 \\
\hline Onion & Number/colony & 3.5 & 5.4 & 0.3 & 0.3 & 9.4 \\
\hline Onion & $\%$ outlets & 37.0 & 57.3 & 2.8 & 2.9 & 100.0 \\
\hline Onion & $\%$ turnover & 68.4 & 25.1 & 2.3 & 4.2 & 100.0 \\
\hline \multicolumn{7}{|l|}{ Fruits } \\
\hline Apple & Number/colony & 2.1 & 3.8 & 0.3 & 0.3 & 6.5 \\
\hline Apple & $\%$ outlets & 32.7 & 59.0 & 4.1 & 4.1 & 100.0 \\
\hline Apple & $\%$ turnover & 43.3 & 47.7 & 4.9 & 4.1 & 100.0 \\
\hline Banana & Number/colony & 2.5 & 5.4 & 0.3 & 0.3 & 8.5 \\
\hline Banana & $\%$ outlets & 29.7 & 63.8 & 3.3 & 3.2 & 100.0 \\
\hline \multirow[t]{2}{*}{ Banana } & $\%$ turnover & 42.7 & 48.1 & 5.8 & 3.4 & 100.0 \\
\hline & & & Closed & Open & & \\
\hline \multicolumn{2}{|c|}{ Processed foods } & Kiranashops & FPS* & FPS* & Modern retail & Total \\
\hline Rice & Number/colony & 10.0 & 1.1 & 0.5 & 0.3 & 11.3 \\
\hline Rice & $\%$ outlets & 87.8 & 9.7 & 4.4 & 2.5 & 100.0 \\
\hline Rice & $\%$ turnover & 83.2 & - & 10.3 & 6.5 & 100.0 \\
\hline Atta & Number/colony & 9.9 & - & - & 0.3 & 10.2 \\
\hline Atta & $\%$ outlets & 97.2 & - & - & 2.8 & 100.0 \\
\hline Atta & $\%$ turnover & 93.5 & - & - & 6.5 & 100.0 \\
\hline Mustard oil & Number/colony & 9.9 & - & - & 0.3 & 10.2 \\
\hline Mustard oil & $\%$ outlets & 97.2 & - & - & 2.8 & 100.0 \\
\hline Mustard oil & $\%$ turnover & 95.7 & - & - & 4.3 & 100.0 \\
\hline
\end{tabular}

* FPS: Fair-Price Shops where they sell rice at subsidized prices for the poor 
Table 8: Food quality on offer in traditional and modern retail

\begin{tabular}{|c|c|c|c|c|c|c|c|}
\hline & \multicolumn{2}{|c|}{ Number varieties on offer } & \multicolumn{3}{|c|}{$\%$ Best quality indicator } & \multicolumn{2}{|c|}{$\%$ Branded/labeled } \\
\hline & Traditional & Modern & Indicator & Traditional & Modern & Traditional & Modern \\
\hline \multicolumn{8}{|l|}{ Vegetables } \\
\hline Tomato & 1.20 & 1.42 & $\%$ no rotten spots & 56.1 & 24.7 & - & - \\
\hline Potato & 1.34 & 1.42 & $\%$ without cutmarks & 54.7 & 29.8 & - & - \\
\hline Onion & 1.16 & 1.36 & $\%$ without spots & 77.3 & 45.6 & - & - \\
\hline \multicolumn{8}{|l|}{ Fruits } \\
\hline \multirow[t]{4}{*}{ Apple } & 1.73 & 2.70 & $\%$ no rotten spots & 53.2 & 35.9 & - & - \\
\hline & & & \% local apple & 84.3 & 58.9 & 8.1 & 41.9 \\
\hline & & & $\%$ imported apple & 15.7 & 41.1 & 44.6 & 79.9 \\
\hline & & & $\%$ total & 100.0 & 100.0 & 13.8 & 57.2 \\
\hline Banana & 1.39 & 1.27 & $\%$ no rotten spots & 54.7 & 20.0 & 0.2 & 18.6 \\
\hline \multicolumn{8}{|c|}{ Processed food } \\
\hline \multirow[t]{5}{*}{ Rice } & 4.12 & 9.15 & & & & & \\
\hline & & & $\%$ basmati & 48.4 & 92.6 & 68.1 & 91.6 \\
\hline & & & $\%$ non-parmal & 32.6 & 4.7 & 1.1 & 42.3 \\
\hline & & & \% parmal & 18.9 & 2.7 & 0.0 & 33.3 \\
\hline & & & $\%$ total & 100.0 & 100.0 & 31.2 & 87.6 \\
\hline Atta & 2.72 & 3.92 & & - & - & 70.1 & 100.0 \\
\hline Mustard oil & 2.12 & 3.15 & & - & - & 78.2 & 100.0 \\
\hline
\end{tabular}


Table 9: T-test price difference modern versus traditional retail

\begin{tabular}{|c|c|c|c|c|c|c|c|}
\hline & \multirow{2}{*}{$\begin{array}{c}\text { Number of } \\
\text { observations }\end{array}$} & \multicolumn{6}{|c|}{ Difference modern retail } \\
\hline & & Mean & Std. Error & Mean & Std. Error & $t$-value & $\operatorname{Pr}(|\mathrm{T}|>|\mathrm{t}|)$ \\
\hline \multicolumn{8}{|l|}{ Vegetables } \\
\hline \multicolumn{8}{|l|}{ Tomato } \\
\hline Modern retail & 85 & 10.10 & 0.22 & & & & \\
\hline Pushcarts & 136 & 12.11 & 0.24 & 2.00 & 0.34 & 5.897 & 0.000 \\
\hline Wet market & 270 & 11.45 & 0.21 & 1.35 & 0.40 & 3.375 & 0.001 \\
\hline \multicolumn{8}{|l|}{ Potato } \\
\hline Modern retail & 84 & 6.24 & 0.13 & & & & \\
\hline Pushcarts & 158 & 7.01 & 0.13 & 0.77 & 0.20 & 3.922 & 0.000 \\
\hline Wet market & 289 & 7.56 & 0.17 & 1.32 & 0.32 & 4.185 & 0.000 \\
\hline \multicolumn{8}{|l|}{ Onion } \\
\hline Modern retail & 79 & 16.79 & 0.38 & & & & \\
\hline Pushcarts & 132 & 18.25 & 0.21 & 1.47 & 0.40 & 3.652 & 0.000 \\
\hline Wet market & 264 & 17.60 & 0.38 & 0.82 & 0.73 & 1.121 & 0.263 \\
\hline \multicolumn{8}{|l|}{ Fruits } \\
\hline \multicolumn{8}{|l|}{ Apple } \\
\hline Modern retail & 144 & 90.70 & 2.75 & & & & \\
\hline Pushcarts & 179 & 69.42 & 1.68 & -21.28 & 3.10 & -6.872 & 0.000 \\
\hline Wet market & 350 & 79.69 & 1.41 & -11.02 & 2.82 & -3.905 & 0.000 \\
\hline \multicolumn{8}{|l|}{ Banana } \\
\hline Modern retail & 70 & 23.63 & 0.55 & & & & \\
\hline Pushcarts & 160 & 24.88 & 0.32 & 1.25 & 0.61 & 2.059 & 0.041 \\
\hline Wet market & 275 & 24.29 & 0.39 & 0.66 & 0.83 & 0.795 & 0.427 \\
\hline \multicolumn{8}{|c|}{ Processed food } \\
\hline \multicolumn{8}{|c|}{ Unbranded Rice } \\
\hline Modern retail & 59 & 31.84 & 1.85 & & & & \\
\hline Kirana shops & 566 & 24.21 & 0.29 & -7.63 & 1.09 & -7.028 & 0.000 \\
\hline \multicolumn{8}{|l|}{ Branded Rice } \\
\hline Modern retail & 489 & 64.75 & 1.18 & & & & \\
\hline Kirana shops & 291 & 69.46 & 1.72 & 4.71 & 2.03 & 2.322 & 0.021 \\
\hline \multicolumn{8}{|l|}{ Atta } \\
\hline Modern retail & 239 & 16.28 & 0.13 & & & & \\
\hline Kirana shops & 584 & 17.28 & 0.09 & 1.00 & 0.16 & 6.125 & 0.000 \\
\hline \multicolumn{8}{|l|}{ Mustard oil } \\
\hline Modern retail & 192 & 79.51 & 0.65 & & & & \\
\hline Kirana shops & 466 & 79.95 & 0.51 & 0.44 & 0.90 & 0.489 & 0.625 \\
\hline
\end{tabular}


Table 10: Hedonic price regression results fruits and vegetables

\begin{tabular}{|c|c|c|c|c|c|c|}
\hline \multirow[t]{2}{*}{ Dep. variable in $\mathrm{Rs} / \mathrm{kg}$} & & \multicolumn{3}{|c|}{ Vegetables } & \multicolumn{2}{|c|}{ Fruits } \\
\hline & & Tomato & Potato & Onion & Apple & Banana \\
\hline \multicolumn{7}{|l|}{ Version 1* } \\
\hline \multirow[t]{2}{*}{ Modern retail dummy } & Coefficient & -2.29 & -0.44 & -0.40 & 8.58 & -1.37 \\
\hline & t-value & -5.35 & -1.72 & -0.59 & 4.19 & -2.33 \\
\hline \multirow[t]{2}{*}{ Wet market dummy } & Coefficient & -0.73 & 0.51 & -0.96 & 4.83 & -0.78 \\
\hline & t-value & -2.43 & 2.57 & -2.60 & 3.70 & -1.95 \\
\hline Number of observations & & 489 & 522 & 473 & 657 & 505 \\
\hline $\mathrm{R} 2$ & & 0.23 & 0.25 & 0.17 & 0.78 & 0.44 \\
\hline \multicolumn{7}{|l|}{ F-tests } \\
\hline \multicolumn{7}{|l|}{ Modern retail versus pushcarts } \\
\hline $\mathrm{F}$ & & 28.59 & 2.95 & 0.35 & 17.59 & 5.41 \\
\hline prob $>F$ & & 0.00 & 0.09 & 0.55 & 0.00 & 0.02 \\
\hline \multicolumn{7}{|l|}{ Modern retail versus wet markets } \\
\hline $\mathrm{F}$ & & 13.29 & 11.05 & 1.02 & 3.72 & 0.77 \\
\hline prob $>\mathrm{F}$ & & 0.00 & 0.00 & 0.31 & 0.05 & 0.38 \\
\hline \multicolumn{7}{|l|}{ Version $2^{*}$} \\
\hline \multirow[t]{2}{*}{ Private-modern retail dummy } & Coefficient & -2.44 & -0.28 & -0.56 & 9.25 & -1.09 \\
\hline & t-value & -5.49 & -1.11 & -0.81 & 4.45 & -1.89 \\
\hline \multirow[t]{2}{*}{ Cooperative-modern retail dummy } & Coefficient & -0.84 & -0.89 & 0.79 & 3.86 & -3.88 \\
\hline & t-value & -0.96 & -1.50 & 0.68 & 1.12 & -1.98 \\
\hline \multirow[t]{2}{*}{ Wet market exit interview dummy } & Coefficient & -0.56 & 1.45 & -1.16 & -0.89 & -1.74 \\
\hline & t-value & -1.37 & 4.79 & -1.73 & 0.57 & -2.82 \\
\hline \multirow[t]{2}{*}{ Wet market trader interview dummy } & Coefficient & -0.90 & -0.36 & -0.75 & 9.38 & 0.04 \\
\hline & t-value & -2.86 & -2.11 & -3.00 & 6.67 & 0.11 \\
\hline \multicolumn{2}{|l|}{ Number of observations } & 489 & 522 & 473 & 657 & 505 \\
\hline \multicolumn{2}{|l|}{$\mathrm{R} 2$} & 0.23 & 0.32 & 0.17 & 0.80 & 0.46 \\
\hline \multicolumn{7}{|l|}{ F-tests } \\
\hline \multicolumn{7}{|l|}{ Modern retail versus pushcarts } \\
\hline \multicolumn{2}{|l|}{$\mathrm{F}$} & 30.16 & 1.24 & 0.66 & 19.81 & 3.56 \\
\hline \multicolumn{2}{|c|}{ prob $>F$} & 0.00 & 0.27 & 0.42 & 0.00 & 0.06 \\
\hline \multicolumn{7}{|c|}{ Modern retail versus exit interview wetmarkets } \\
\hline \multicolumn{2}{|c|}{$\mathrm{F}$} & 13.25 & 24.16 & 1.00 & 21.31 & 0.61 \\
\hline \multicolumn{2}{|c|}{ prob $>F$} & 0.00 & 0.00 & 0.32 & 0.00 & 0.44 \\
\hline \multicolumn{7}{|c|}{ Modern retail versus wet market trader interview } \\
\hline \multicolumn{2}{|c|}{$\mathrm{F}$} & 11.67 & 0.09 & 0.07 & 0.00 & 3.64 \\
\hline \multicolumn{2}{|l|}{ prob $>F$} & 0.00 & 0.76 & 0.79 & 0.95 & 0.06 \\
\hline Modern retail versus Safal & & & & & & \\
\hline $\mathrm{F}$ & & 3.44 & 1.08 & 1.92 & 2.25 & 1.98 \\
\hline prob $>F$ & & 0.06 & 0.30 & 0.17 & 0.13 & 0.16 \\
\hline
\end{tabular}

* $\mathrm{P}$ in Rs/kg = f(retail outlets, quality/branded indicators, ward dummy, wealth colony dummy)

Only retail outlet coefficients are reported

Pushcart prices are the default 
Table 11: Hedonic price regression results processed products

\begin{tabular}{|c|c|c|c|}
\hline \multirow[t]{2}{*}{ Dep. variable in $\mathrm{Rs} / \mathrm{kg}$} & \multicolumn{3}{|c|}{ Processed products } \\
\hline & Rice & Atta & Mustard oil \\
\hline \multicolumn{4}{|l|}{ Modern retail dummy } \\
\hline Coefficient & -5.81 & -7.27 & -3.69 \\
\hline t-value & -3.34 & -5.41 & -4.79 \\
\hline Log(quantity) & \multicolumn{3}{|c|}{ Included but not shown } \\
\hline Type of rice dummies & \multicolumn{3}{|c|}{ Included but not shown } \\
\hline Branded dummy & \multicolumn{3}{|c|}{ Included but not shown } \\
\hline Ward dummies & \multicolumn{3}{|c|}{ Included but not shown } \\
\hline Wealth colony dummies & \multicolumn{3}{|c|}{ Included but not shown } \\
\hline Intercept & \multicolumn{3}{|c|}{ Included but not shown } \\
\hline Number of observations & 1368 & 671 & 652 \\
\hline R2 & 0.56 & 0.88 & 0.43 \\
\hline \multicolumn{4}{|l|}{ F-test } \\
\hline \multicolumn{4}{|c|}{ Modern retail versus kirana stores } \\
\hline F-test & 11.15 & 29.30 & 22.93 \\
\hline prob $>F$ & 0.00 & 0.00 & 0.00 \\
\hline
\end{tabular}


Table 12: PSM results of price comparisons of modern versus traditional retail

\begin{tabular}{|c|c|c|c|c|c|}
\hline Sample & $\begin{array}{l}\text { Treated } \\
\text { (modern) }\end{array}$ & $\begin{array}{c}\text { Controls } \\
\text { (traditional) }\end{array}$ & Difference & Std. Error & T-stat. \\
\hline \multicolumn{6}{|l|}{ Vegetables } \\
\hline \multicolumn{6}{|l|}{ Tomato } \\
\hline Unmatched & 10.07 & 11.66 & -1.59 & 0.37 & -4.29 \\
\hline ATT* & 10.03 & 11.30 & -1.27 & 0.56 & -2.26 \\
\hline Number of obs. & 75 & 399 & & & \\
\hline \multicolumn{6}{|l|}{ Potato } \\
\hline Unmatched & 6.23 & 7.31 & -1.07 & 0.27 & -3.98 \\
\hline ATT & 6.27 & 6.77 & -0.50 & 0.49 & -1.03 \\
\hline Number of obs. & 41 & 431 & & & \\
\hline \multicolumn{6}{|l|}{ Onion } \\
\hline Unmatched & 16.82 & 17.02 & -0.20 & 0.39 & -0.51 \\
\hline ATT & 16.49 & 15.95 & 0.54 & 0.59 & 0.91 \\
\hline Number of obs. & 72 & 262 & & & \\
\hline \multicolumn{6}{|l|}{ Fruits } \\
\hline \multicolumn{6}{|l|}{ Apple } \\
\hline Unmatched & 90.40 & 76.41 & 13.98 & 2.62 & 5.34 \\
\hline ATT & 86.01 & 76.36 & 9.64 & 5.42 & 1.78 \\
\hline Number of obs. & 105 & 513 & & & \\
\hline \multicolumn{6}{|l|}{ Banana } \\
\hline Unmatched & 23.63 & 24.40 & -0.77 & 0.70 & -1.11 \\
\hline ATT & 23.69 & 22.96 & 0.15 & 0.98 & 0.15 \\
\hline Number of obs. & 69 & 429 & & & \\
\hline \multicolumn{6}{|l|}{ Processed food } \\
\hline \multicolumn{6}{|l|}{ Rice } \\
\hline Unmatched & 61.28 & 39.69 & 21.59 & 1.55 & 13.89 \\
\hline ATT & 61.28 & 69.12 & -7.84 & 2.40 & -3.27 \\
\hline Number of obs. & 532 & 813 & & & \\
\hline \multicolumn{6}{|l|}{ Atta } \\
\hline Unmatched & 135.92 & 122.86 & 13.06 & 3.19 & 4.09 \\
\hline ATT & 135.92 & 145.37 & -9.46 & 4.02 & -2.35 \\
\hline Number of obs. & 229 & 427 & & & \\
\hline \multicolumn{6}{|l|}{ Mustard oil } \\
\hline Unmatched & 79.49 & 82.78 & -3.29 & 0.72 & -4.55 \\
\hline ATT & 79.58 & 82.97 & -3.39 & 0.85 & -4.00 \\
\hline Number of obs. & 178 & 410 & & & \\
\hline
\end{tabular}

*ATT: Average treatment effect for the treated 
${ }^{1}$ He shows that when Hong Kong was in the very early stages of supermarket penetration in the 1970 s, the quality and price of both processed foods (including rice) and fresh produce was much higher in supermarkets than in traditional stores.

${ }^{2}$ While we will end by positing some determinants of the findings of differences, it is beyond the scope of the paper to examine the procurement systems and in-store handling practices of the retailers.

${ }^{3}$ Mostly staples like rice, wheat flour, edible oils, condiments, and other processed foods, but seldom fresh fruits and vegetables except at times for long-shelf life basics.

${ }^{4}$ Some cooperatives play an important role in the marketing and processing of some selected agricultural products. Major commodities handled by cooperatives are food grains, jute, cotton, sugar, milk and areca nuts.

${ }^{5}$ This initial rise then decline of retail cooperativism is a common finding in other developing countries and Western Europe and the US (Reardon and Gulati, 2008).

${ }^{6}$ Rashid et al. (2008) argue that the Great Bengal Famine in 1943 was the event that provided the momentum by the Indian government to intervene in grain markets. It was then believed that private markets failed as there was no a particular shortage of food in that year.

${ }^{7}$ The degree of intervention in food grain markets has increased significantly over the years. Its market share in wheat (rice) markets has increased from 4\% (9\%) to in 1967/68 to 25\% (22\%) in 2004. In 2006, it procured 15 million tons of wheat and 27 million tons of rice, representing respectively $21 \%$ and $29 \%$ of total production in that year.

${ }^{8}$ This growth might even be an underestimation as region-specific chains and "non-traditional" retail chains like Mother Dairy with its 1000 kiosks in Delhi are not included.

${ }^{9}$ The total food/grocery sales imply roughly $2 \%$ of total food retail in India is sold via modern retail outlets (Reardon et al. 2008); other calculations (such as Joseph et al. 2008, using a smaller set of modern retailers) estimate the share at around $1 \%$.

${ }^{10}$ The Municipal Corporation of Delhi accounts for $94 \%$ of the National Capital Territory and caters to over 13 million people.

${ }^{11}$ In our definition, a wetmarket was defined as a cluster of at least 10 fruits and vegetables traders. 
${ }^{12}$ Fair Price Shops are officially closed for one day a week. During the week, they are supposed to be open from 9 am to $7 \mathrm{pm}$ with a break of two hours from $1 \mathrm{pm}$ to $3 \mathrm{pm}$.

13 This is roughly on par with what is found in modern retail in most developing countries in Asia (Reardon and Gulati, 2008).

${ }^{14}$ For international reference, in July 2009 the exchange rate is about 49 rupees per US dollar and 68 rupees per Euro.

15 through Stata's psmatch2 command.

${ }^{16}$ An example of an expression of this conventional wisdom was a statement to the press by an official of the Ministry of Consumer Affairs in India: "Consumers need value for money from retail trade because they are often cheated by shopkeepers in the unorganised retail sector" (Hindu Business Line, 2005).

${ }^{17}$ Note that our findings regarding the shares in total retail turnover for both processed foods and fresh produce exceed by 2-3 times the national-level share estimates. This is because modern retail is so far nearly only in cities, and among those, mainly in the largest ("Tier 1" cities like Delhi). Moreover, earlier published estimates are not based on survey results, unlike ours.

${ }^{18}$ The Municipal Council of Delhi has divided all the colonies in the city based on property prices from a scale of $\mathrm{A}$ (the richest) to $\mathrm{H}$ (the poorest colonies) for taxation purposes. The data can be found on the webpage: http://www.mcdpropertytax.in/colonylist.php

${ }^{19}$ Rottenness in the case of tomato, apple, and banana; cut marks in the case of potato; and the presence of white spots in the case of onion.

${ }^{20}$ Including Safal, given its resemblance to a modern retail set-up.

21 They include for tomato: variety, size, ripeness, shape, rottenness; for potato: size, age potato, shape, cleanliness, cut marks; for onion: size, presence of spots, presentation, color; banana: size, ripeness, rottenness; apple: variety, size, rottenness, ripeness, freshness, fungus infected, spots; rice: grain length, grain color, shape rice, degree of brokenness, impurities due to rock particles, impurities due to leftovers from bran or husk; mustard oil: branded; atta: branded.

${ }^{22}$ Based on data from the National Account Statistics, Annual Survey of Industries, and Agricultural Statistics at a Glance, the share of all processed and raw agricultural and food exports over production is estimated at $5.7 \%$ in 2006 . The share of modern retail in India is estimated at 2.3\%, using consumption data of the National Sample Survey of 2005-2006 and 
extrapolating our Delhi data to urban areas as a whole and assuming negligible share of modern retail in rural areas.

${ }^{23}$ However, this might change quickly as has been shown in South-Africa (e.g. D'Haese and Van Huylenbroeck, 2005). 